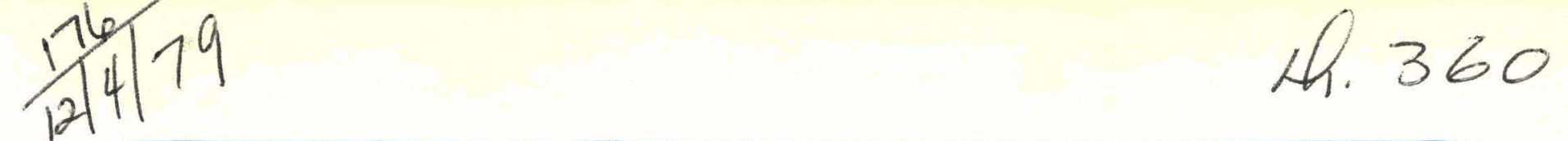

GA-A15569 UC-77

\title{
PERSONNEL RADIATION EXPOSURE IN HTGR AND LWR PLANTS
}

\author{
by \\ B. A. ENGHOLM
}

Prepared under

Contract DE-AT03-76ET35300

for the San Francisco Operations Office

Department of Energy

\section{DATE PUBLISHED: SEPTEMBER 1979}

\section{GENERAL ATOMIC COMPANY}




\section{DISCLAIMER}

This report was prepared as an account of work sponsored by an agency of the United States Government. Neither the United States Government nor any agency Thereof, nor any of their employees, makes any warranty, express or implied, or assumes any legal liability or responsibility for the accuracy, completeness, or usefulness of any information, apparatus, product, or process disclosed, or represents that its use would not infringe privately owned rights. Reference herein to any specific commercial product, process, or service by trade name, trademark, manufacturer, or otherwise does not necessarily constitute or imply its endorsement, recommendation, or favoring by the United States Government or any agency thereof. The views and opinions of authors expressed herein do not necessarily state or reflect those of the United States Government or any agency thereof. 


\section{DISCLAIMER}

Portions of this document may be illegible in electronic image products. Images are produced from the best available original document. 


\section{NOTICE}

This report was prepared as an account of work sponsored by the United States Government. Neither the United States nor the United States Department of Energy, nor any of their employees, nor any of their contractors, subcontractors, or their employees, makes any warranty, express or implied, or assumes any legal liability or responsibility for the accuracy, completeness or usefulness of any information, apparatus, product or process disclosed, or represents that its use would not infringe privately owned rights.

Printed in the United States of America Available from

National Technical Information Service U.S. Department of Commerce 5285 Port Royal Road Springfield, Virginia 22161

Price: Printed Copy $\$ 4.00$; Microfiche $\$ 3.00$ 
GA-A15569

UC-77

\title{
PERSONNEL RADIATION EXPOSURE IN HTGR AND LWR PLANTS
}

\author{
by \\ B. A. ENGHOLM
}

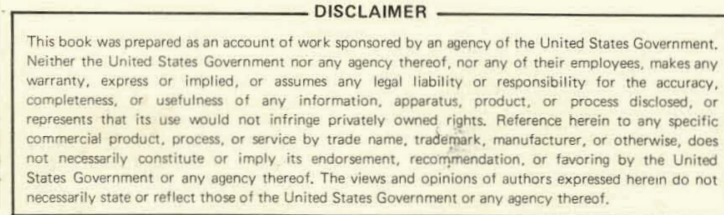

Prepared under

Contract DE-AT03-76ET35300

for the San Francisco Operations Office

Department of Energy

GENERAL ATOMIC PROJECT 6400

DATE PUBLISHED: SEPTEMBER 1979

\section{GENERAL ATOMIC COMPANY}


THIS PAGE

WAS INTENTIONALLY

LEFT BLANK 
1. SUMMARY . . . . . . . . . . . . . . . . . . . . . . 1-1

2. LWR INFORMATION . . . . . . . . . . . . . . . . . . 2-1

2.1. Total Exposure . . . . . . . . . . . . . . . 2-1

2.2. Refueling Exposure . . . . . . . . . . . . . . 2-1

3. РЕAСН ВОТТОМ 1 . . . . . . . . . . . . . . . . . 3-1

3.1. Total Exposure . . . . . . . . . . . . . . 3-1

3.2. Refueling Exposure . . . . . . . . . . . . . 3-1

4. FORT ST. VRAIN . . . . . . . . . . . . . . . . . 4-1

4.1. Total Exposure .. . . . . . . . . . . . . . . 4-1

4.2. Refueling Exposure ................ . . 4-3

5. LARGE HTGR STEAM CYCLE . . . . . . . . . . . . . . . 5-1

6. CONCLUSIONS . . . . . . . . . . . . . . . . . . . 6-1

7. REFERENCES . . . . . . . . . . . . . . . . . . . 7-1

\section{FIGURES}

3-1. Cumulative occupational exposures for early, low-power nuclear plants.................. 3-3

4-1. Cumulative occupational exposures for medium-power nuclear plants . . . . . . . . . . . . . . . . . 4-4

5-1. Cumulative occupational exposure for large nuclear plants (Part 1) ..................... . . 5-3

5-2. Cumulative occupational exposure for farge nuclear plants (Part 2) . . . . . . . ............. 5-4

5-3. Cumulative occupational exposure for large nuclear plants (Part 3) . . . . . . . . . . . . . . . 5 5-5

\section{TABLES}

3-1. Peach Bottom HTGR operating experience . . . . . . . . . 3-2

4-1. FSV man-rem experience . . . . . . . . . . . . . . . 4 4-2

5-1. Man-rem predictions for LHTGR-SC . . . . . . . . . . . 5-2 


\section{SUMMARY}

Occupational radiation exposures at HTGR plants were compared with those at typical LWR facilities. Actual man-rem accumulations at the Peach Bottom 1 HTGR and at the Fort St. Vrajn HTGR have been substantially lower than those at LWRs with similarly rated powers, when compared on the basis of man-rem/GW(e)y.

The expected exposure rate for a large HTGR steam cycle or gas turbine unit is $70 \mathrm{man}-\mathrm{rem} / \mathrm{GW}(\mathrm{e}) \mathrm{y}$, while the design basis is $180 \mathrm{man}-\mathrm{rem} / \mathrm{GW}(\mathrm{e}) \mathrm{y}$.

The results from Peach Bottom and FSSV lend credence to these predictions, as do the exposures experienced in $\mathrm{CO}_{2}$-cooled reactors with PCRVs. The comparable figure for actual LWR experience is $57.0 \mathrm{man}-\mathrm{rem} / \mathrm{GW}(\mathrm{e}) \mathrm{y}$. 


\section{LWR INFORMATION}

\subsection{TOTAL EXPOSURE}

Numerous reports and articles have appeared in recent years pointing up the increasing problem of occupational radiation exposures at LWR plants. The most convenient collection of such information, especially for earlier data extending back to 1961, is Pohl's article, Ref, 2-1. Figures 1 through 6 from this article have been combined, augmented, and redrawn as Figs. 3-1, 4-1, 5-1, 5-2, and 5-3 of thị report. The LWR comparisons which follow are based on these figures.

\subsection{REFUELING EXPOSURE}

Information on occupational exposure during LWR refueling is available from Ref. 2-2. The actual experienced exposure is 239 man-rem per LWR refueling in 1976. Westinghouse has projected an exposure of 10.5 man-rem for rapid refueling (Ref. 2-3). 


\section{PEACH ВOTTOM 1}

\subsection{TOTAL EXPOSURE}

The Peach Bottom HTGR, operated by Philadelphia Electric Company, generated a total of $1200 \mathrm{GW}(e) h$ of net power during its operating life of March 3, 1966 to October 31, 1974 (Ref. 3-1).

Personnel exposures during Peach Bottom operation, maintenance, and refueling were exceptionally low, according to records of Philadelphia Electric health physicists (Ref. 3-2).

Yearly and cumulative exposure and power generation data are listed in Table 3-1.

Since the Peach Bottom HTGR produced $40 \mathrm{MW}(\mathrm{e})$ and was a prototype reactor, comparisons are made with the following early, low-power LWRs:

$\begin{array}{ll}\text { Big Rock } & 63 \mathrm{MW}(\mathrm{e}) \\ \text { Humbolt } & 63 \\ \text { Lacrosse } & 48\end{array}$

Exposure data for these LWRs were obtained from Ref. $2-1$ and are plotted in Fig. 3-1, which depicts the cumulative ocçupational exposures for all four plants. The rate of man-rem exposure at Peach Bottom 1 [183 man-rem/GW(e)y] can be compared with the LWR accumulation rate of over 2000 man-rem/GW(e)y.

\subsection{REFUELING EXPOSURE}

No separate data are available for Peach Bottom refueling exposures, but the personnel exposure is estimated by this author to be less than 1 man-rem per refueling. 
TABLE 3-1

PEACH BOTTOM HTGR OPERATING EXPERIENCE

\begin{tabular}{c|c|c|c|c|c}
\hline \multirow{2}{*}{$\begin{array}{c}\text { Year of } \\
\text { Operation }\end{array}$} & \multicolumn{2}{|c|}{ Man-Rem Exposure } & \multicolumn{2}{|c|}{$\begin{array}{c}\text { Net Power Generation } \\
{[\text { GW(e)y] }}\end{array}$} & $\begin{array}{c}\text { Cumulative } \\
\text { Occupational } \\
\text { Exposure }\end{array}$ \\
\cline { 2 - 5 } By Year & Cumulative & By Year & Cumulative & [man-rem/GW(e)y] \\
\hline 1967 & $\sim 3$ & $\sim 3$ & 0.017 & 0.017 & 176 \\
1968 & $\sim 3$ & $\sim 6$ & 0.015 & 0.032 & 188 \\
1969 & $\sim 3$ & $\sim 9$ & 0.0157 & 0.048 & 188 \\
1970 & $\sim 3$ & $\sim 12$ & 0.0163 & 0.068 & $\vdots$ \\
1971 & $\sim 4$ & $\sim 16$ & 0.024 & 0.088 & 176 \\
1972 & $\sim 3$ & $\sim 19$ & 0.012 & 0.102 & 182 \\
1973 & $\sim 3$ & 22 & 0.021 & 0.1205 & 183 \\
1974 & NA & NA & 0.0183 & 0.140 & NA \\
\hline
\end{tabular}




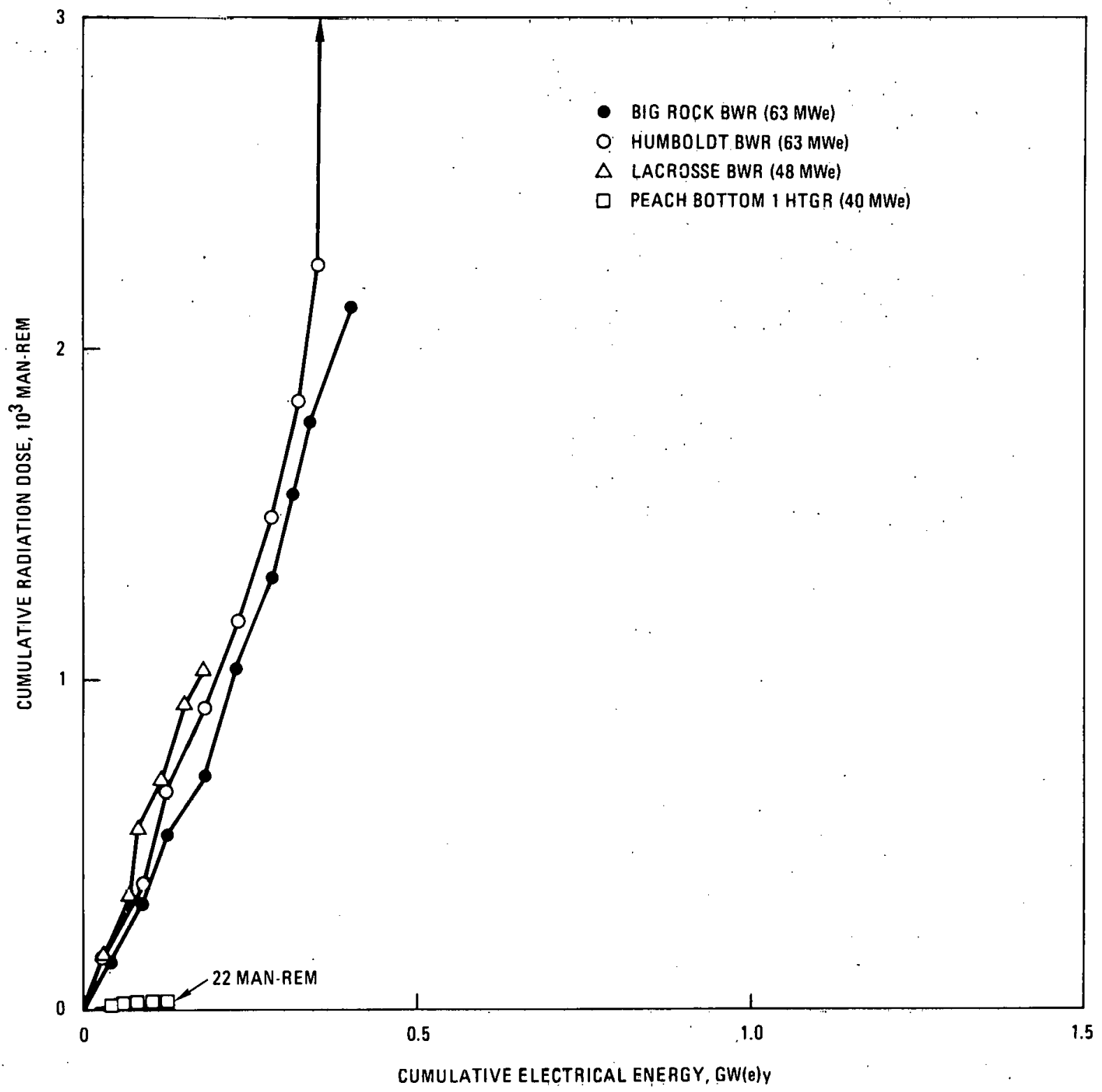

Fig. 3-1. Cumulative occupational exposures for early, low-power nuclear plants 


\section{FORT ST. VRAIN}

\subsection{TOTAL EXPOSURE}

The Fort St. Vrain Nuclear Generating Station had accumulated 953 GW(e)h of net power output up to the February. 8, 1979 shutdown for refueling, according to reports of Public Service Company of Colorado (PSC). Net power generation for calendar 1977 and 1978 is also available from these reports.

The PSC Health Physics office maintains detailed records of personnel radiation exposure, in compliance with State and Federal regulations. Data for 1977 and 1978 were obtained from Dr. Don Alexander, head of PSC Health Physics.

Information needed for a comparison with LWR experience is summarized in Table 4-1.

It is believed appropriate to compare FSV experience with the following T.WR.s :

$\begin{array}{ll}\text { Dresden } 1 & 200 \mathrm{MW}(\mathrm{e}) \\ \text { Ginna } & 490 \\ \text { Indian Pt. } 1 & 265 \\ \text { San Onofre 1 } & 436 \\ \text { Yankee Rowe } & 175 .\end{array}$

In addition, operating data for the British Oldbury GCR plant (which utilizes a PCRV) were collected from Nuclear Engineering International magazine for purposes of an independent compartson. The results, in 
TABLE $\quad$-1

FSV MAN-REM EXPERIENCE

\begin{tabular}{|c|c|c|c|c|}
\hline Personnel & Exposure & $\begin{array}{l}\text { Averaged } \\
\text { Man-Rem }\end{array}$ & $\begin{array}{l}\text { Net Power } \\
\text { Generation } \\
\text { [GW(e)y] }\end{array}$ & $\begin{array}{c}\text { Rate of } \\
\text { Accumulation } \\
{[\mathrm{man}-\mathrm{rem} / \mathrm{GW}(\mathrm{e}) \mathrm{y}]}\end{array}$ \\
\hline 1977 & & & & \\
\hline 946 & None & 0 & & \\
\hline 55 & $<100$ mrem & 2.75 & & \\
\hline 1 & $100-250$ mrem & 0.175 & & \\
\hline 1978 & & 2.9 & 0.0256 & 113 \\
\hline 896 & None & 0 & & \\
\hline 34 & $<100$ mrem & 1.7 & & \\
\hline 0 & $100-250 \mathrm{mrem}$ & 0 & . & \\
\hline & & 1.7 & 0.0695 & 24 \\
\hline Cumulative & & 4.6 & 0.0951 & 48 \\
\hline
\end{tabular}


Fig. 4-1, show that the FSV curve barely rises above the zero ordinate, closely following the early operational experience at 01dbury and San Onofre. All the other LWRs show up poorly by comparison.

\subsection{REFIJELING EXPOSURE}

The first refueling of the Fort St. Vrain HTGR took place in March and April 1979. During these refueling operationș, numerous gamma dose rate measurements were made by PSC health physicists and by GAC personnel. A comparison between measurements and calculations is being prepared for issuance as a GA report (Ref. 4-1).

Most of the refueling dose rates were so low as to require the use of a microrem meter by PSC health physicists. For instance, the average dose rate on the accessible surface of the fuel handling machine (FHM) when loaded with spent fuel was less than $1 \mathrm{mrem} / \mathrm{hr}$. The only time personnel are near the loaded FHM is during unbolting, crane, and bolting operations, about half an hour per fuel region. Assuming six personnel and six fuel regions, the man-rem exposure for this part of refueling would be:

$$
\frac{6 \times 6 \times 0.5 \times 1}{1000}=0.018 \text { man-rem } .
$$

Control rod drive (CRD) handling operations were equally inconsequential in exposure, except for one CRD which had activated clevis pins. In this case, the dose rate at some distance from the auxiliary transfer cask (ATC) was about $4 \mathrm{mrem} / \mathrm{hr}$ (i.e., at the change area). Hence, it is possible that another 0.02 man-rem could have been accumulated in moving this CRD to the storage wells.

Health physicists made one-Lime measurcments at greater elevations of the Fort St. Vrain FHM and ATC, where the surface dose rates are intentionally higher than those within an $8-\mathrm{ft}$ height above the refueling floor. It is possible that a few tenths of a man-rem could have been accumulated by these health physicists in this fashion. 


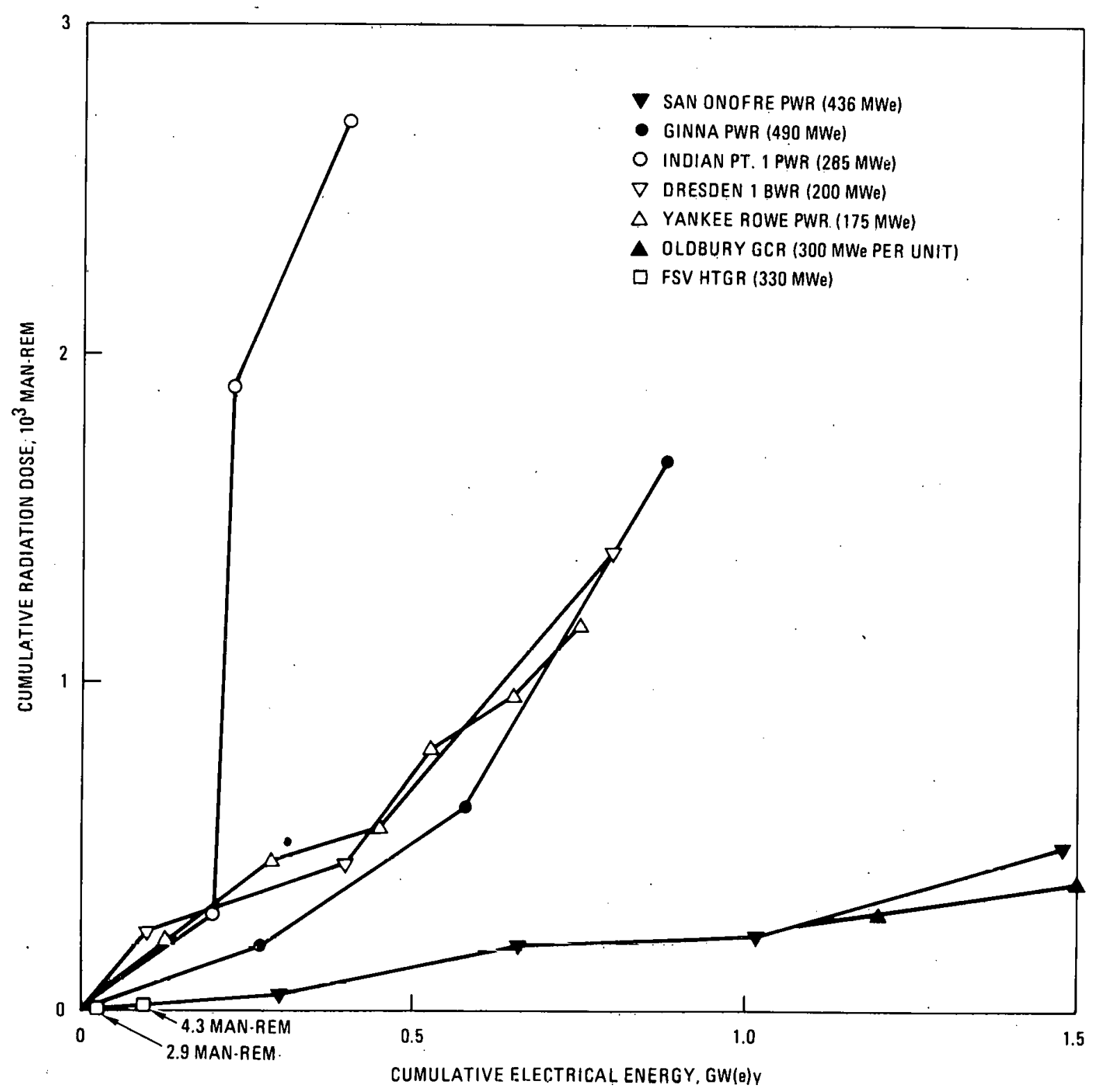

Fig. 4-1. Cumulative occupational exposures for medium-power nuclear plants 
Public Service of Colorado will in due course publish tabulations of personnel exposure during the first FSV refueling. It is expected that the total accumulation was less than 0.5 man-rem.

In order to compare this figure with LWR experience, it should be remembered that (1) FSV had not exceeded $\sim 65 \%$ of full power rating, i.e., the plant had been generating about $200 \mathrm{MW}(\mathrm{e})$; and (2) the spent fuel had decayed for a period of 45-60 days. The 60-day decay time reduces the La140 inventory in the fuel blocks by a factor of 25 .

On the other hand, if the design dose rate of $10 \mathrm{mrem} / \mathrm{hr}$ had existed on the surface of the FHM, somewhat more stringent access control and personnel scheduling measures would have been taken. Hence, it is probable that the refueling personnel exposure under full power normal operating conditions will be less than 5 man-rem. This figure, when scaled to 1000 MW(e), becomes 15 man-rem, still considerably lower than current experience in most LWR plants.

\footnotetext{
*Preliminary information obtained through K. R. Van Howe of S. M. Stoller Corp. indicates an actual accumulation of 0.22 man-rem.
} 


\section{LARGE HTGR STEAM CYCLE}

Information on occupational exposure for the Large HTGR-SC was based on a comprehensive study of a $900 \mathrm{MW}(\mathrm{e})$ plant design (Ref. 5-1).

Only preliminary work has been done on assessing man-rem exposures associated with the Gas Turbine HTGR. Reference 5-2 reports that the exposure for turbomachine removal is 2.1 man-rem, but no predictions have been made regarding subsequent decontamination and disassembly. Until more information becomes available, it would be expected that the occupational exposure for the GT-HTGR would be the same as that for the HTGR-SC.

Man-rem results for the HTGR-SC are summarized in Table 5-1.

The expected accumulation rate for the LHTGR is plotted with recent LWR data in Figs. 5-1 through 5-3. Also shown is information on the British Wylfa GCR plant (using a PCRV), obtained from Nuclear Engineering : International.

The results show that the expected rate of man-rem accumulation in the LHTGR is about a factor of 8 below that of LWR plants. 
TABLE 5-1

MAN-REM PREDICTIONS FOR LHTGR-SC

\begin{tabular}{|c|c|c|c|c|}
\hline \multirow[b]{2}{*}{ Type of Operation } & \multicolumn{4}{|c|}{ Annual Man-Rem Exposure for 900 MW(e) Unit } \\
\hline & Expected & Desig & n Bas: & \\
\hline Refueling & 5.5 & & 20 & \\
\hline $\begin{array}{l}\text { Reactor Operation } \\
\text { and Surveillance }\end{array}$ & $7.0^{*}$ & & 20 & \\
\hline $\begin{array}{l}\text { NSS Maintenance } \\
\text { and ISI }\end{array}$ & 10.1 & & 20 & \\
\hline BOP Maintenance & $25.0^{* *}$ & & 50 & \\
\hline Special Maintenance & $\frac{3.2^{* * *}}{50.8}$ & & $\frac{20}{130}$ & \\
\hline Rate of Accumulation & & & & \\
\hline $\begin{array}{l}{[900 \mathrm{MW}(\mathrm{e}), 80 \%} \\
\text { load factor] }\end{array}$ & $\frac{50.8}{0.9 \times 0.8}=70 \frac{\text { man-rem }}{G W(e) y}$ & $\frac{130}{0.9 \times 0.8}$ & $=180$ & $\frac{\operatorname{man}-r e m}{G W(e) y}$ \\
\hline
\end{tabular}

*From low-level noble gas activity in containment building. ** Assumed; no information is available from an architect-engineer. $* * *$ Tube plugging every year @ 1.0 man-rem; steam-generator removal every 10 years @ 1.65 man-rem; circulator removal every 2 years @ 1.0 man-rem. 


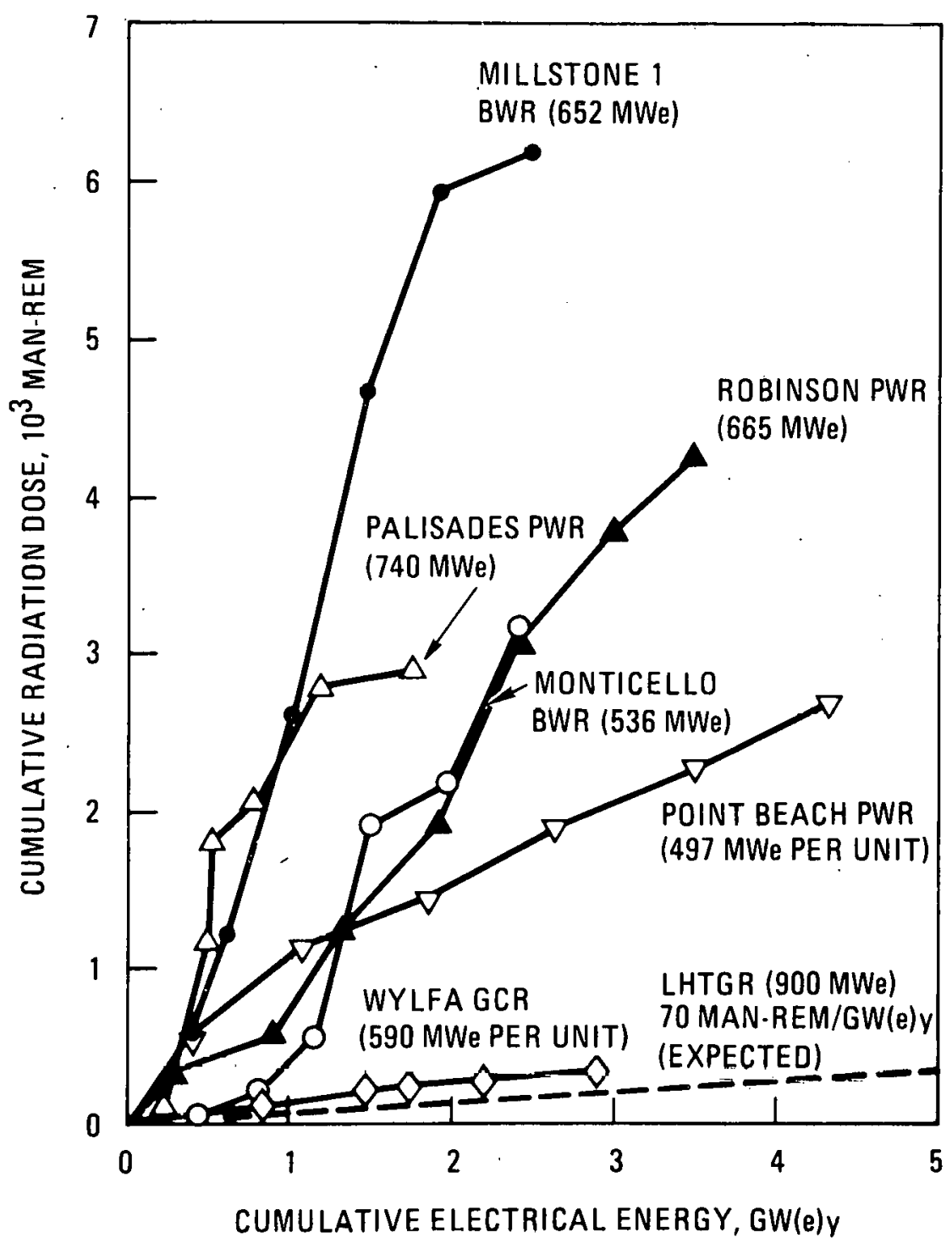

Fig. 5-1. Cumulative occupational exposure for large nuclear plants (Part 1) 


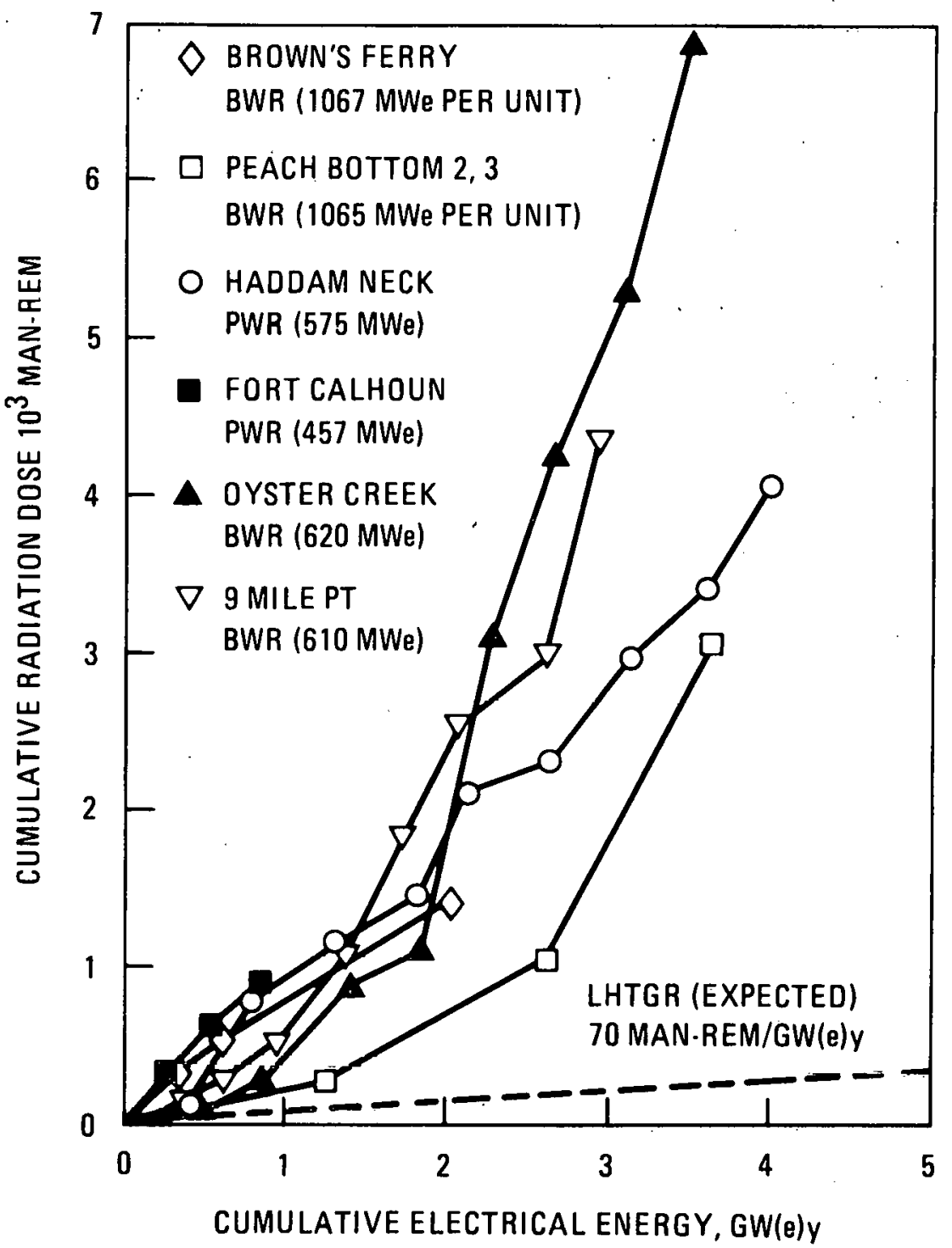

Fig. 5-2: Cumulative occupational exposure for large nuclear plant.s (Part 2) 


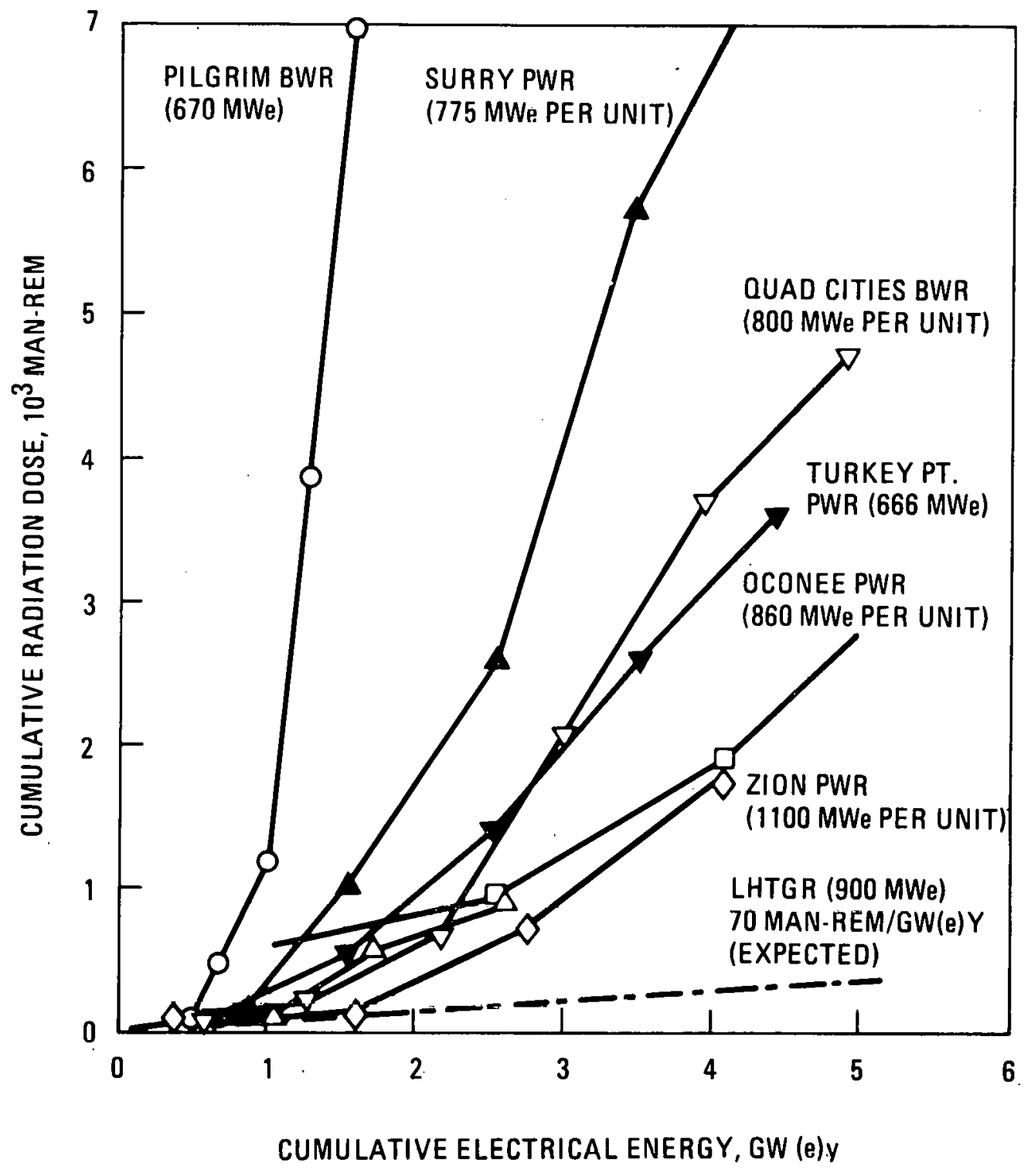

Fig. 5-3. Cumulative occupational exposure for large nuclear pl.ants (Part 3) 


\section{CONCLUSIONS}

Available data on man-rem exposures of working personnel at nuclear plants from Refs. 2-1, 2-2 and elsewhere, clearly indicate that GCRs are experiencing less dose accumulation than LWRs. Reactors of the HTGR type, both Peach Bottom and Fort St. Vrain, as well as LHTGR designs, fall in line with this observation, having man-rem/GW(e)y accumulations about an order of magnitude less than LWRs. 


\section{REFERENCES}

2-1. Pohl, K. 0., "Radiation exposure in LWR's higher than predicted," Nuclear Engineering International, February 1979, pp. 36-38.

2-2. Johnson, L. A., "Occupational Radiation Exposure at Light Water Couled Reactors, 1976," NUREG-0323, March 1978.

2-3. Lutz, R. J., Jr., "Techniques to Reduce Occupational Radiation Exposures," ANS Winter Meeting, San Francisco, November 27. December 2, 1977.

3-1. Scheffel, W. J., et al., "Operating History Report for the Peach Bottom HTGR," GA-A13907, August 31, 1976.

3-2. Kohler, E., and N. Gazda, Philadelphia Electric Company, personal communication, August 1979.

4-1. Engholm, B. A., "FSV Refueling Equipment - Calculations vs. Measurements," GA-A15451, in preparation.

5-1. Engholm, B. A., and S. Su, "Shielding Design Report for the 900 MW(e) HTGR Steam Cycle Reference Plant," General Atomic Company unpublished data.

5-2. "GT-HTGR Plant Maintenance Studies," GA-A14858, Appendix A, March 1979. 


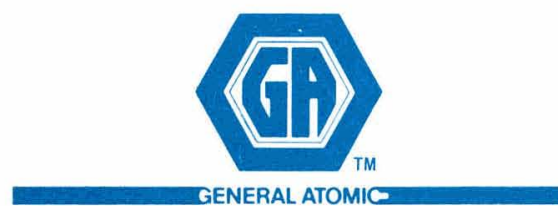

GENERAL ATOMIC COMPANY P. O. BOX 81608

SAN DIEGO, CALIFORNIA 92138 